\title{
Synergistic effect of scavenger receptor $A$ and low-density lipoprotein receptor on macrophage foam cell formation under inflammatory stress
}

\author{
TIANYI SU ${ }^{1}$, LEI ZHAO ${ }^{2}$, XIONGZHONG RUAN $^{2}$, GUOQING ZUO $^{3}$ and JIANPING GONG ${ }^{1}$ \\ ${ }^{1}$ Chongqing Key Laboratory of Hepatobiliary Surgery and Department of Hepatobiliary Surgery, \\ Second Affiliated Hospital to Chongqing Medical University; ${ }^{2}$ Department of Center for Lipid Research, \\ Chongqing Medical University; ${ }^{3}$ Department of Gastroenterology, Second Affiliated Hospital \\ to Chongqing Medical University, Chongqing, P.R. China
}

Received December 8, 2011; Accepted March 19, 2012

DOI: $10.3892 / \mathrm{mmr} .2012 .1170$

\begin{abstract}
To provide experimental evidence for the effect of inflammation on cholesterol accumulation in macrophages, we investigated the expression of low-density lipoprotein receptor (LDL-R) and scavenger receptor A (SR-A) genes and proteins in the lipopolysaccharide (LPS)-stimulated macrophagelike RAW264.7 cell line. RAW264.7 cells were incubated in serum-free medium in the absence or presence of LDL alone, LDL + LPS and LPS alone. Intracellular cholesterol content, tumor necrosis factor $\alpha$ levels in the supernatants, mRNA and protein expression of LDL-R and SR-A in the treated cells were assessed by Oil Red O staining cholesterol enzymatic assay, enzyme-linked immunosorbent assay, semi-quantitative polymerase chain reaction and western blot analysis, respectively. Our results demonstrated that LPS was able to upregulate SR-A mRNA and protein expression, override LDL-R suppression induced by a high dose of LDL and increase LDL uptake by enhancing receptor expression, leading to foam cell formation in RAW264.7 cells. These findings suggest that the synergy of the upregulation of SR-A and dysregulation of LDL-R under inflammatory stress may contribute to macrophage-derived foam cell formation.
\end{abstract}

\section{Introduction}

Atherosclerosis is characterized by the accumulation of lipids, mainly cholesterol and cholesterol esters, and the infiltration of inflammatory cells, particularly macrophages. Recent experimental and clinical evidence suggest that inflammation plays a significant role in lipid-mediated cell injury (e.g., atherosclerosis) (1-4). Retention of lipoproteins in the artery

Correspondence to: Dr Jianping Gong, Department of Hepatobiliary Surgery, Secondary Affiliated Hospital to Chongqing Medical University, Chongqing 400010, P.R. China

E-mail: gongjianping11@126.com

Key words: scavenger receptor type A, low-density lipoprotein receptor, RAW264.7 macrophages, atherosclerosis, inflammation wall is one of the primary events in atherosclerosis $(5,6)$. In the vessel wall, low-density lipoprotein (LDL) is trapped by matrix proteoglycans and becomes susceptible to various modifications that trigger local inflammatory responses leading to recruitment of macrophages in the arterial wall (7). Uptake of modified LDL by macrophages leads to foam cell formation, which is characteristic of early atherosclerotic lesions (8).

Cardiovascular risk is increased in chronic inflammatory states, up to 33-fold in patients with renal failure and 50-fold in patients with immune dysregulation (9-12). These diseases are often associated with inflammatory stress with elevated inflammatory markers and inflammatory cytokines. However, most mechanisms linking atherosclerosis to inflammatory stress remain to be identified. Inflammation and infection may affect the plasma levels of cholesterol and lipoproteins by modulating the synthesis and secretion of apolipoproteins, the activity of lipolytic enzyme or the expression of lipoprotein receptors. Two of the major determinants of plasma cholesterol levels are the result of the activity of the scavenger receptor A (SR-A), mediating uptake of modified LDL and LDL receptor (LDL-R), and mediating uptake of native LDL in macrophages. SR-A is expressed in human atherosclerotic lesions $(13,14)$, and they have been shown to contribute to the uptake of modified LDL (15). Since this uptake of cholesterol through the macrophage scavenger receptors is poorly regulated, excess cholesterol accumulation leads to macrophage-derived foam cell formation. Macrophages play a very important role in the pathogenesis of atherosclerosis and are one of the major cell types involved in foam cell formation (16). However, the role of LDL-R and SR-A receptor in macrophages under inflammation remains unclear. The present experiment set out to investigate the effects of LPS on cholesterol accumulation in macrophages, and the expression of LDL-R and SR-A genes and proteins in the lipopolysaccharide (LPS)-stimulated macrophage-like RAW264.7 cell line in the presence of a high dose of native LDL.

\section{Materials and methods}

Cell culture. The macrophage-like RAW264.7 cell line was cultured in growth medium containing RPMI-1640 medium, 
$10 \%$ newborn bovine serum, $2 \mathrm{mmol} / 1$ glutamine, $100 \mathrm{U} / \mathrm{ml}$ penicillin and $100 \mu \mathrm{g} / \mathrm{ml}$ streptomycin. All experiments were carried out in serum-free RPMI-1640 medium containing $0.2 \% \mathrm{BSA}, 2 \mathrm{mmol} / \mathrm{l}$ glutamine, $100 \mathrm{U} / \mathrm{ml}$ penicillin and $100 \mu \mathrm{g} / \mathrm{ml}$ streptomycin. All reagents for cell culture and LPS were obtained from Sigma. LDL was isolated from healthy human plasma by sequential ultra-centrifugation.

Enzyme-linked immunosorbent assay (ELISA) for tumor necrosis factor $\alpha(T N F-\alpha)$. Cultures of RAW264.7 cells were washed twice with PBS at $37^{\circ} \mathrm{C}$ and then overlaid with $1 \mathrm{ml}$ of fresh, serum-free RPMI-1640 medium. After an incubation of $24 \mathrm{~h}$, an additional $1 \mathrm{ml}$ of medium with or without $100 \mathrm{ng} / \mathrm{ml}$ LPS was added. Cells were incubated for the desired time periods. The concentrations of TNF- $\alpha$ in cell culture medium were determined by an ELISA assay kit (eBioscience, UK) according to the manufacturer's instructions.

Measurement of intracellular cholesterol. The method was based on the cholesterol enzymatic assay described by Gallo et al and Gamble et al $(17,18)$. RAW264.7 cells in 6-well plates were cultured in serum-free medium without (control) or with $100 \mu \mathrm{g} / \mathrm{ml}$ LDL in the absence or presence of $100 \mathrm{ng} /$ $\mathrm{ml}$ LPS for $24 \mathrm{~h}$. Cells were then washed twice in PBS, intracellular lipids were extracted in isopropanol and dried under vacuum, and total cholesterol (TC), free cholesterol (FC) and cholesterol ester (CE) content were measured by enzymatic assay $(\mathrm{CE}=\mathrm{TC}-\mathrm{FC})$ and normalized by total cell proteins determined by the modified Lowry assay.

Oil Red $O$ stain. RAW264.7 cells were incubated in serum-free medium for $24 \mathrm{~h}$. Then, these cells were differentially treated. After $24 \mathrm{~h}$, cells were fixed using $5 \%$ formalin for $30 \mathrm{~min}$ at room temperature, soaked in Oil Red O staining solution for $30 \mathrm{~min}$ at room temperature and washed three times, followed by hematoxylin stain to visualize the nucleus.

Total RNA isolation and semi-quantitative RT-PCR. Total RNA was isolated from cultured cells using TRIzol reagent (Promega, USA). Total RNA (500 ng) was used as a template for RT using an RT kit from Toyoba. The RT reaction was set up in a $20-\mu 1$ mixture containing $50 \mathrm{mmol} / 1 \mathrm{KCl}, 10 \mathrm{mmol} / \mathrm{l}$ Tris- $\mathrm{HCl}, 5 \mathrm{mmol} / 1 \mathrm{MgCl}_{2}, 1 \mathrm{mmol} / \mathrm{l}$ of each deoxynucleoside triphosphate, $2.5 \mu \mathrm{mol} / 1$ random hexamers, 20 units RNAase inhibitor and 50 units Moloney-murine leukemia virus RT. Incubations were performed in a DNA Thermal Cycler (Eppendorf, USA) for $10 \mathrm{~min}$ at room temperature, followed by $30 \mathrm{~min}$ at $42^{\circ} \mathrm{C}$ and $5 \mathrm{~min}$ at $99^{\circ} \mathrm{C}$. Semi-quantitative PCR was performed in a DNA Thermal Cycler (Eppendorf) using PCR Master mix (DongSheng Biotec Co., China). Thermal cycler conditions contained holds for $10 \mathrm{~min}$ at $95^{\circ} \mathrm{C}$, followed by 30 cycles of $30 \mathrm{sec}$ at $95^{\circ} \mathrm{C}, 30 \mathrm{sec}$ at $51^{\circ} \mathrm{C}$ and $45 \mathrm{sec}$ at $72^{\circ} \mathrm{C}$. The PCR products were separated by electrophoresis and the relative amount of mRNA was calculated using the Genegenus system and GeneTools software version 3.05 (Synoptics, UK). GAPDH served as the reference housekeeping gene. The following oligonucleotide primers were used: SR-A upper 5'-TCAATGACAGCATCCCTTCC-3', lower 5'-ATGTCCTCCTGTTGCTTTGC-3'; LDL-R upper
5'-TTGCAGTAGAAGACTCAGGC-3, lower 5'-ATGATT TGCAGCGGAAGTGG-3'; GAPDH upper 5'-ATTCAACGG CACAGTCAA-3', lower3'-TGAGGGTGAGAAGGTGGAA-5'.

Western blot analysis. Cells from a $150-\mathrm{ml}$ culture bottle were pooled and allowed to swell at $4^{\circ} \mathrm{C}$ in $300 \mu \mathrm{l}$ of lysis buffer (10 mmol/1 HEPES, pH 7.9, $10 \mathrm{mmol} / 1 \mathrm{KCL}$, $1.5 \mathrm{mmol} / 1 \mathrm{MgCl}_{2}, 0.5 \mathrm{mmol} / 1$ dithiothreitol, 0.4 Nonidet $\mathrm{P}-40,0.5 \mu \mathrm{mol} / \mathrm{l}$ phenylmethylsulfonyl fluoride and $1 \mu \mathrm{g} / \mathrm{ml}$ of antipain, leupeptin, bestatin and chymostatin) and then passed through a 23 -gauge needle 20 times before centrifugation at $14,000 \mathrm{x} \mathrm{g}$ at $4^{\circ} \mathrm{C}$ for $15 \mathrm{~min}$. The supernatant from this spin was used as the whole cell extract. Identical amounts of total protein from the whole cell extract were denatured and then subjected to electrophoresis on a 5\% stacking and $8 \%$ separating SDS polyacrylamide gel in a Bio-Rad Mini Protein apparatus. Electrophoretic transfer to nitrocellulose was accomplished at $60 \mathrm{~V}, 200 \mathrm{~mA}$ for $2 \mathrm{~h}$ in $25 \mathrm{mmol} / 1 \mathrm{Tris}$, $\mathrm{pH} 8.3,192 \mathrm{mmol} / 1$ glycine, $0.1 \%$ SDS and 20\% methanol. The membrane was then blocked with $5 \%$ skimmed milk for $1 \mathrm{~h}$ at room temperature, followed by two 5-min washes in PBST (phosphate-buffered saline/1\% Tween). The membrane was incubated with the first antibody (goat-anti SR-A, or rabbit-anti LDL-R, rabbit-anti SREBP-2; Santa Cruz, USA) for $2 \mathrm{~h}$ at $37^{\circ} \mathrm{C}$ in antibody dilution buffer (1\% BSA in PBST). The horseradish peroxidase-labeled secondary antibody (rabbit anti-goat, goat-anti rabbit; Santa Cruz) was diluted in antibody dilution buffer and then added to the membrane for $1 \mathrm{~h}$ at $37^{\circ} \mathrm{C}$, followed by three 5-min washes in PBST. Finally, detection procedures were performed using ECL Advance Western Blotting Detection kit, in a Genegnome system (Synoptics). Band intensity volumes were measured by Quantity One software (Bio-Rad, UK).

Immunocytochemical staining. RAW264.7 cells were fixed using $5 \%$ formalin for $30 \mathrm{~min}$ at room temperature, and then washed three times, followed by immunocytochemical staining according to the kit (Boshide Bio-Project Co., Wuhan, China) instructions. The first antibody was rabbit anti-rabbit LDL-R antibody. Phosphate-buffered saline (PBS) substituted for the first antibody was used as the negative control. Cells with brown granules appearing in the nuclei were considered to be positively stained and indicated activation of LDL-R.

Statistical analysis. In the experiments, data are expressed as the means \pm standard deviation (SD). Comparisons between two groups were performed by t-test. All analyses were carried out using the SPSS software (version 13.0; SPSS Inc., Chicago, IL, USA). P-values $<0.05$ were considered to indicate statistical significance.

\section{Results}

Expression levels of TNF- $\alpha$ in ELISA. We examined LPS-dependent TNF- $\alpha$ secretion in RAW264.7 cells to determine whether LPS induces TNF- $\alpha$ secretion in a timedependent manner and whether LPS causes inflammatory stress. LPS-treated RAW264.7 cells secreted TNF- $\alpha$, with levels beginning to increase at $4 \mathrm{~h}$ of incubation and reaching a maximum at $16 \mathrm{~h}$ and lasting until $48 \mathrm{~h}$. 
A

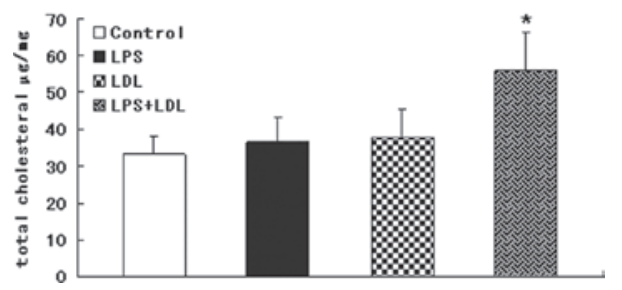

B

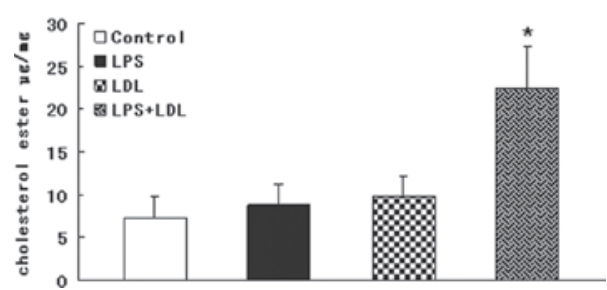

Figure 1. Effect of LPS on intracellular cholesterol accumulation in the RAW264.7 cell line. Cells $\left(5 \times 10^{6}\right.$ cells $\left./ \mathrm{ml}\right)$ were incubated in serum-free medium for $24 \mathrm{~h}$. The medium was then replaced by fresh serum-free RPMI1640 medium (control), medium added together with $100 \mu \mathrm{g} / \mathrm{ml} \mathrm{LDL}$ alone (LDL), $100 \mathrm{ng} / \mathrm{ml}$ LPS alone (LPS), or medium with $100 \mu \mathrm{g} / \mathrm{ml} \mathrm{LDL}$ and $100 \mathrm{ng} / \mathrm{ml}$ LPS (LDS+LPL) for $24 \mathrm{~h}$. The cells were collected for (A) total cholesterol assay and (B) cholesterol ester assay, as described in Materials and methods. The results were normalized for total cellular protein and represent the means \pm SD from three independent experiments (triplicate cultures). ${ }^{*} \mathrm{P}<0.05$ (two-sided), significantly different from the group treated with control by t-test.

Intracellular cholesterol accumulation in the cholesterol enzymatic assay. We examined the effect of LPS $(100 \mathrm{ng} / \mathrm{ml})$ on the intracellular cholesterol content in RAW264.7 cells. Inflammation resulted in a TC and CE accumulation and foam cell formation in RAW264.7 cells, as evidence by the intracellular total cholesterol assay (Fig. 1A) and cholesterol ester assay (Fig. 1B).

Intracellular cholesterol accumulation as assessed by Oil Red $O$ staining. Staining of RAW264.7 cells with Oil Red O after incubation with $100 \mu \mathrm{g} / \mathrm{ml} \mathrm{LDL}$ or $100 \mathrm{ng} / \mathrm{ml}$ LPS alone showed a slight increase in lipid droplets over that of the control group (Fig. 2A-C). However, a significant increase in cholesterol accumulation was observed in RAW264.7 cells in the presence of $100 \mu \mathrm{g} / \mathrm{ml} \mathrm{LDL}$ and $100 \mathrm{ng} / \mathrm{ml}$ LPS together (Fig. 2D). These data were consistent with the cholesterol enzymatic assay data.

Expression levels of $L D L-R$ and SR-A mRNA in RT-PCR. To assess how LPS induces an increase in intracellular cholesterol content, the mRNA and protein levels of LDL-R and SR-A in RAW264.7 cells were evaluated. RAW264.7 cells were stimulated with $100 \mu \mathrm{g} / \mathrm{ml} \mathrm{LDL,} 100 \mathrm{ng} / \mathrm{ml}$ LPS, or with $100 \mu \mathrm{g} / \mathrm{ml} \mathrm{LDL}$ and $100 \mathrm{ng} / \mathrm{ml} \mathrm{LPS}$, respectively, for up to 24 h. mRNA was measured by semi-quantitative RT-PCR. Either LDL loading or LPS increased SR-A mRNA expression in RAW264.7 cells (Fig. 3A). LDL loading inhibited LDL-R mRNA expression and LPS disrupted this physiological feedback causing an increase in LDL-R mRNA levels in RAW264.7 cells (Fig. 3B).

Western blot analysis of the expression levels of $L D L-R$ and $S R$-A protein. Western blotting demonstrated that LDL loading
A

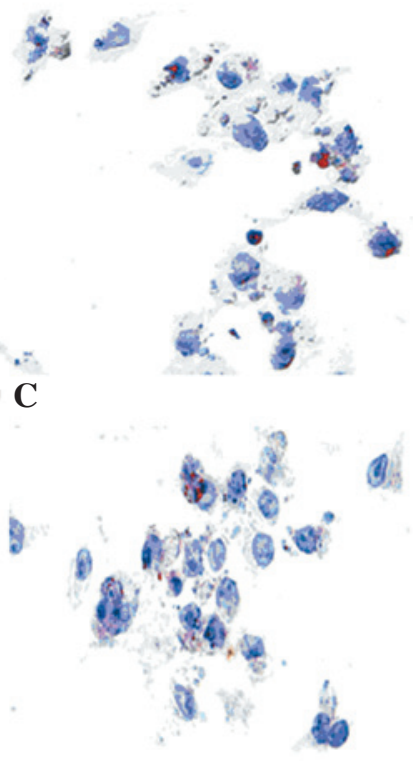

B
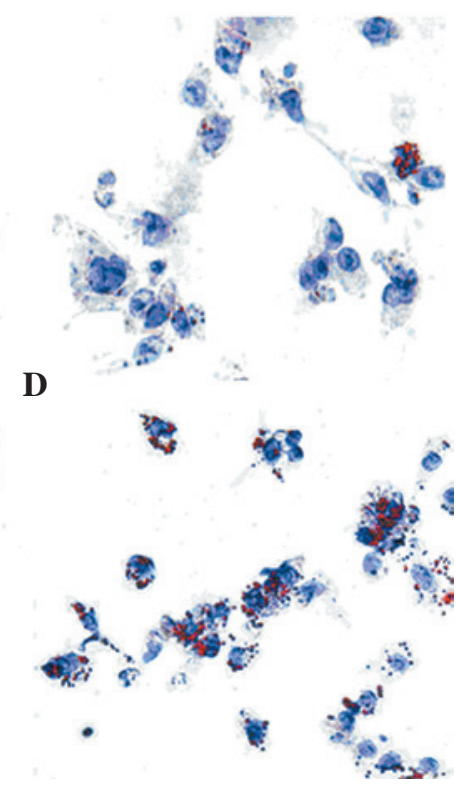

Figure 2. Intracellular cholesterol accumulation in RAW264.7 cells by Oil Red staining (SP 10x40). RAW264.7 cells were incubated in serum-free medium for $24 \mathrm{~h}$. The medium was then replaced with fresh serum-free RPMI-1640 medium (control; A), medium added together with $100 \mu \mathrm{g} / \mathrm{ml}$ LDL alone (LDL; B), $100 \mathrm{ng} / \mathrm{ml}$ LPS alone (LPS; C), or medium with $100 \mu \mathrm{g} /$ $\mathrm{ml} \mathrm{LDL}$ and $100 \mathrm{ng} / \mathrm{ml}$ LPS (LDL+LPS; D). After $24 \mathrm{~h}$, cells were fixed using $5 \%$ formalin for $30 \mathrm{~min}$ at room temperature, then soaked in Oil Red staining solution for $30 \mathrm{~min}$ at room temperature, and washed three times, followed by hematoxylin staining to visualize the nucleus.

or LPS increased SR-A protein expression in RAW264.7 cells $(\mathrm{P}<0.05)$ (Fig. 4A). LDL loading inhibited LDL-R protein levels (vs. control, $\mathrm{P}<0.05$ ) and LPS increased LDL-R levels in RAW264.7 cells (vs. LDL loading group, $\mathrm{P}<0.05$ ) (Fig. 4B). These data were consistent with mRNA data.

Immunocytochemical analysis of $L D L-R$ protein expression. Immunocytochemical staining showed that LDL inhibited LDL-R protein expression and LPS (100 ng/ml) overrode the suppression of the LDL-R protein expression induced by LDL loading (Fig. 5).

\section{Discussion}

As foam cell formation has long been deemed critical to lesion development, the scavenger receptors involved in lipid uptake have been causally implicated in the pathogenesis of atherosclerosis. Several studies have shown that macrophages are deemed to cause foam cells, have multiple functions, including secretion and production of growth factors, cytokines, clearance of particles in blood, and also play a key role in atherosclerosis by expression of several different cell surface receptors that can be modulated by inflammation, for cholesterol uptake and foam cell formation $(16,19)$. SR-A is an important cell surface receptor for binding modified-LDL and plays a central role in atherosclerosis. LDL-R is the primary receptor for binding and internalization of plasma-derived LDL cholesterol and regulates plasma LDL concentrations. With respect to macrophages, several studies, although not all, have shown the effect of SR-A or LDL-R alone on foam 
A
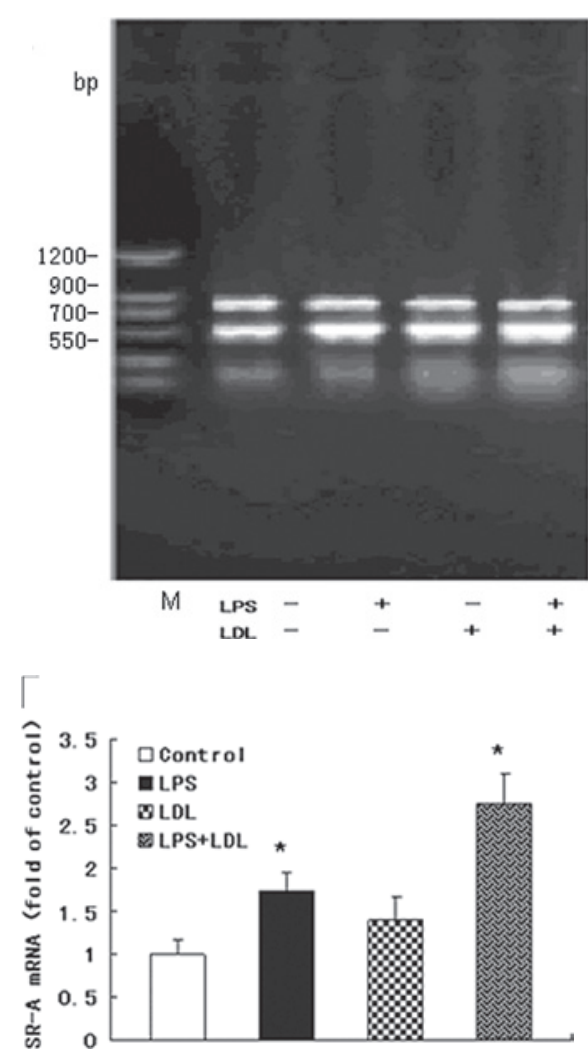

B

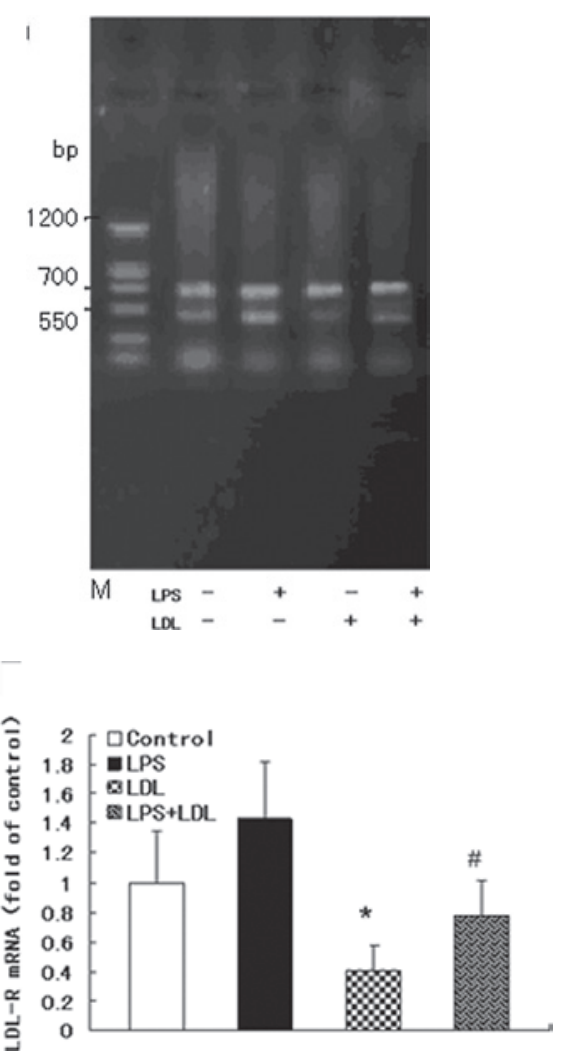

Figure 3. Expression of (A) SR-A and (B) LDL-R mRNA in RAW264.7 cells by RT-PCR analysis. Cells were incubated in serum-free medium for $24 \mathrm{~h}$. Then, the medium was replaced with fresh serum-free RPMI-1640 medium (control), medium together with $100 \mu \mathrm{g} / \mathrm{ml} \mathrm{LDL}$ alone (LDL), $100 \mathrm{ng} / \mathrm{ml}$ LPS alone (LDS), or medium with $100 \mu \mathrm{g} / \mathrm{ml} \mathrm{LDL}$ and $100 \mathrm{ng} / \mathrm{ml} \mathrm{LPS}$ (LPS+LDL). RNA was prepared and RT-PCR was performed, as described in Materials and methods. Expected lengths: SR-A 550 bp; LDL-R 410 bp; GAPDH 720 bp. M, marker. Values shown are the means \pm SD of three independent experiments (triplicate cultures). "P $<0.05$ (two-sided), significantly different from the control by t-test. " $\mathrm{P}<0.05$ (two-sided), significantly different from the group treated with LDL by t-test.

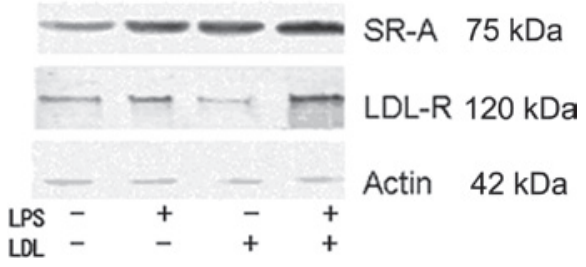

A

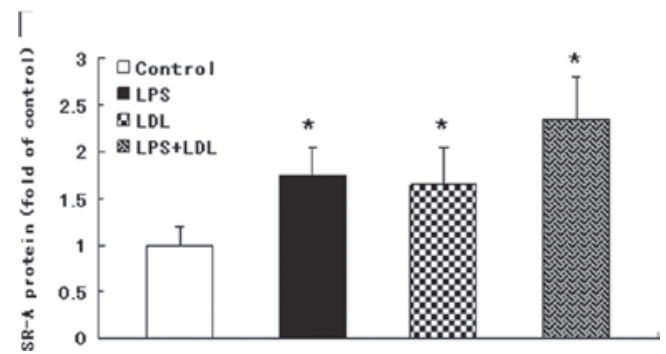

B

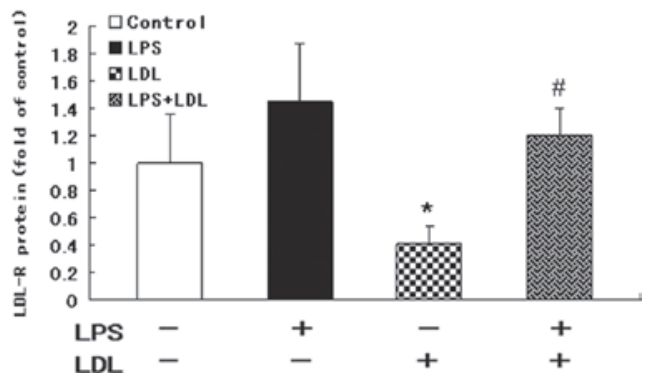

Figure 4. Western blotting of (A) SR-A and (B) LDL-R protein expression in RAW264.7 cells. Cells were incubated in serum-free medium for $24 \mathrm{~h}$. Then, the medium was replaced with fresh serum-free RPMI-1640 medium (control), medium together with $100 \mu \mathrm{g} / \mathrm{ml}$ LDL alone (LDL), $100 \mathrm{ng} / \mathrm{ml}$ LPS alone (LPS), or medium with $100 \mu \mathrm{g} / \mathrm{ml}$ LDL and $100 \mathrm{ng} / \mathrm{ml} \mathrm{LPS} \mathrm{(LDS+LPL).}$ " $\mathrm{P}<0.05$ (two-sided), significantly different from the control by $\mathrm{t}$-test. ${ }^{*} \mathrm{P}<0.05$ (two-sided), significantly different from the group treated with LDL by t-test.

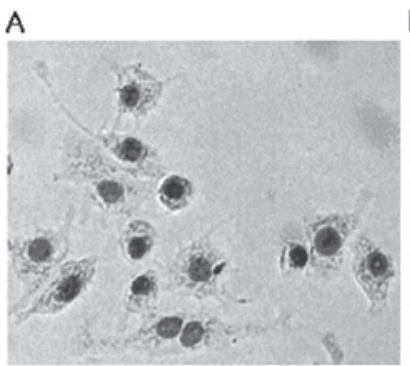

B

C

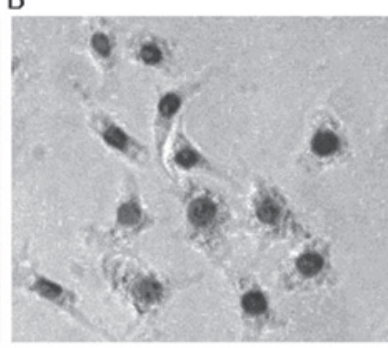

D

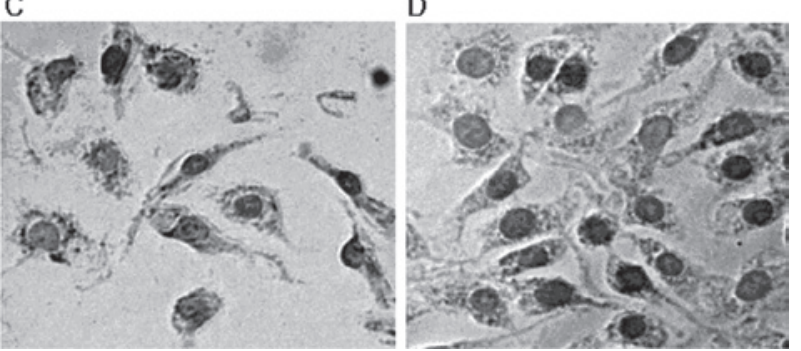

Figure 5. Protein levels of LDL-R in immunocytochemistry (SP 10x40). RAW264.7 cells were incubated in serum-free medium for $24 \mathrm{~h}$. Then, the medium was replaced with fresh serum-free RPMI-1640 medium (control; A), medium together with $100 \mu \mathrm{g} / \mathrm{ml}$ LDL alone (B), $100 \mathrm{ng} / \mathrm{ml}$ LPS alone (C), or medium with $100 \mu \mathrm{g} / \mathrm{ml} \mathrm{LDL}$ and $100 \mathrm{ng} / \mathrm{ml}$ LPS (D). After $24 \mathrm{~h}$, cells were fixed using $5 \%$ formalin for $30 \mathrm{~min}$ at room temperature, and immunocytochemical staining was performed according to the kit instructions. Finally, hematoxylin was used to visualize the nucleus. 
cell formation under inflammation, however, reports on the synergic effect of LDL-R and SR-A on macrophage foam cell formation are limited. In the present study, we mainly focus on receptor-mediated macrophage-derived foam cell formation under LPS-induced inflammatory stress.

SR-A, as a classical atherogenic receptor (20-22), has been studied for decades. Scavenger receptor was coined to describe the activity of macrophages which mediate the uptake of modified forms of LDL. As a central feature of the pathology of atherosclerosis, macrophage-derived foam cells are closely resembled by the resultant lipid laden macrophages (23). The class A scavenger receptor was shown to be a trimeric Type II membrane protein with a broad range of polyanionic ligands, including components of Gram-positive bacterial cell walls and modified forms of LDL, LPS of Gram-negative bacteria (24). Compared to macrophages from wild-type animals, macrophages of SR-A-silenced mice exhibit $70-80 \%$ reduced uptake of acetylated LDL (25). Certain studies also have shown that inflammatory cytokines mediate the regulation of SR-A and foam cell formation on macrophages in atherosclerosis (26), as well as LPS induces SR-A expression in RAW264.7 cells (27). However, more and more studies suggest that SR-A is not the only receptor responsible for atherosclerosis.

It is well known that the high incidence of atherosclerosis is correlated with the high concentration of LDL and cholesterol in plasma. The activity of the LDL-R is another major determinant of plasma cholesterol levels. The cellular uptake and degradation of plasma is mediated by the LDL-R. It has been reported that the activity of LDL-R is normally under tight metabolic control via a feedback system, which is dependent on intracellular cholesterol concentration (28-31). The system maintains a constant level of cholesterol in cells by controlling both the rate of cholesterol synthesis and the rate of cholesterol uptake from LDL. The feedback regulation is controlled through specific interactions of the sterol-regulatory element (SRE)-1 of the LDL-R promoter and a family of SRE-binding proteins (SREBPs), namely, SREBP-1 and SREBP-2 (32-35). Moreover, a number of pro-inflammatory cytokines, such as interleukin-6, oncostatin $\mathrm{M}$ and TNF- $\alpha$, have been shown to increase LDL-R gene expression under inflammatory stress (36-38). We previously demonstrated in human vascular smooth muscle cells and mesangial cells that inflammatory cytokines disrupt LDL-R feedback regulation, allowing unregulated uptake of cholesterol in the cells causing foam cell formation (39-42). However, the role of the LDL-R in cholesterol accumulation in macrophages remains to be elucidated.

In the present study, we investigated the effects of native LDL that consist mostly of cholesterol of plasma in circulation and macrophage-derived foam cells under inflammatory stress, and evaluated the roles of SR-A and LDL-R in this process. We demonstrated that LPS causes inflammatory stress and induces TNF- $\alpha$ secretion in a time-dependent manner consequently. LPS increased intracellular cholesterol accumulation in the RAW264.7 macrophage-like cell line (Fig. 1) and caused foam cell formation (Fig. 2). To explore the molecular mechanisms, we further determined the expression levels of LDL-R and SR-A mRNA and protein in RAW264.7 cells and found that, under physiological conditions, LDL-R was sensitive for downregulation of LDL loading. Intracellular
TC and CE contents remained at a relatively constant level in the RAW264.7 cells. However, inflammation overrode this tight feedback and caused foam cell formation via increased expression of both SR-A and LDL-R (Figs. 3-5). The results of our study indicate that the synergy of dysregulation of LDL-R under inflammatory stress and upregulation of SR-A may contribute to macrophage-derived foam cell formation.

In conclusion, our findings indicate that a novel role for the synergy of upregulation of SR-A and dysregulation of LDL-R plays a significant role in macrophage foam cell formation under inflammatory stress.

\section{Acknowledgements}

The authors acknowledge the support of the National Natural Science Foundation of China (nos. 30530360 and 30772098).

\section{References}

1. Libby P, Ridker PM and Hansson GK: Inflammation in atherosclerosis: from pathophysiology to practice. J Am Coll Cardiol 54: 2129-2138, 2009.

2. Galkina $E$ and Ley K: Immune and inflammatory mechanisms of atherosclerosis. Annu Rev Immunol 27: 165-197, 2009.

3. Krupinski J, Font A, Luque A, Turu M and Slevin M: Angiogenesis and inflammation in carotid atherosclerosis. Front Biosci 13: 6472-6482, 2008.

4. Tahara N, Imaizumi T, Virmani R and Narula J: Clinical feasibility of molecular imaging of plaque inflammation in atherosclerosis. J Nucl Med 50: 331-334, 2009.

5. Williams KJ and Tabas I: The response-to-retention hypothesis of early atherogenesis. Arterioscler Thromb Vasc Biol 15: $551-561,1995$.

6. Ylä-Herttuala S,Solakivi T,Hirvonen J,et al: Glycosaminoglycans and apolipoproteins B and A-I in human aortas: chemical and immunological analysis of lesion-free aortas from children and adults. Arteriosclerosis 7: 333-340, 1987.

7. Steinberg D, Parthasarathy S, Carew TE, et al: Beyond cholesterol. Modifications of low-density lipoprotein that increase its atherogenicity. N Engl J Med 320: 915-924, 1989.

8. Li AC and Glass CK: The macrophage foam cell as a target for therapeutic intervention. Nat Med 8: 1235-1242, 2002.

9. Pennant M, Davenport C, Bayliss S, Greenheld W, Marshall T and Hyde C: Community programs for the prevention of cardiovascular disease: a systematic review. Am J Epidemiol 172: 501-516, 2010.

10. Bash LD, Erlinger TP, Coresh J, Marsh-Manzi J, Folsom AR and Astor BC: Inflammation, hemostasis, and the risk of kidney function decline in the Atherosclerosis Risk in Communities (ARIC) Study. Am J Kidney Dis 53: 596-605, 2009.

11. Sherer Y, Zinger H and Shoenfeld Y: Atherosclerosis in systemic lupus erythematosus. Autoimmunity 43: 98-102, 2010.

12. Doria A: Atherosclerosis and lupus: what we know and what we should know. J Rheumatol 36: 2380-2382, 2009.

13. Ylä-Herttuala S, Rosenfeld ME, Parthasarathy S, et al: Gene expression in macrophage-rich human atherosclerotic lesions: 15-lipoxygenase and acetyl low density lipoprotein receptor messenger RNA colocalize with oxidation specific lipid-protein adducts. J Clin Invest 87: 1146-1152, 1991.

14. Kunjathoor VV, Febbraio M, Podrez EA, et al: Scavenger receptors class A-I/II and CD36 are the principal receptors responsible for the uptake of modified low density lipoprotein leading to lipid loading in macrophages. J Biol Chem 277: 49982-49988, 2002.

15. Suzuki H, Kurihara Y, Takeya M, et al: A role for macrophage scavenger receptors in atherosclerosis and susceptibility to infection. Nature 386: 292-296, 1997.

16. Shibata $\mathrm{N}$ and Glass CK: Regulation of macrophage function in inflammation and atherosclerosis. J Lipid Res 50: S277-S281, 2009.

17. Gallo LL, Atasoy R, Vahouny GV and Treadwell CR: Enzymatic assay for cholesterol ester hydrolase activity. J Lipid Res 19: 913-916, 1978. 
18. Gamble W, Vaughan M, Kruth HS and Avigan J: Procedure for determination of free and total cholesterol in micro- or nanogram amounts suitable for studies with cultured cells. J Lipid Res 19: 1068-1070, 1978

19. Saha P, Modarai B, Humphries J, Mattock K, Waltham M, Burnand KG and Smith A: The monocyte/macrophage as a therapeutic target in atherosclerosis. Curr Opin Pharmacol 9: 109-118, 2009.

20. Jozefowski S, Arredouani M, Sulahian T and Kobzik L: Disparate regulation and function of the class A scavenger receptors SR-AI/ II and MARCO. J Immunol 175: 8032-8041, 2005.

21. Neyen C, Plüddemann A, Roversi P, Thomas B, Cai L, van der Westhuyzen DR, Sim RB and Gordon S: Macrophage scavenger receptor A mediates adhesion to apolipoproteins A-I and E. Biochemistry 48: 11858-11871, 2009.

22. Greaves DR and Gordon S: The macrophage scavenger receptor at 30 years of age: current knowledge and future challenges J Lipid Res 50: S282-S286, 2009.

23. Osto E, Kouroedov A, Mocharla P, Akhmedov A, Besler C Rohrer L, von Eckardstein A, Iliceto S, Volpe M, Lüscher TF and Cosentino F: Inhibition of protein kinase Cbeta prevents foam cell formation by reducing scavenger receptor A expression in human macrophages. Circulation 118: 2174-2182, 2008.

24. Plüddemann A, Neyen C and Gordon S: Macrophage scavenger receptors and host-derived ligands. Methods 43: 207-217, 2007.

25. Van Berkel TJ, Van Eck M, Herijgers N, Fluiter K and Nion S: Scavenger receptor classes A and B: their roles in atherogenesis and the metabolism of modified LDL and HDL. Ann NY Acad Sci 902: 113-126, 2000 .

26. Li K, Yao W, Zheng X and Liao K: Berberine promotes the development of atherosclerosis and foam cell formation by inducing scavenger receptor A expression in macrophage. Cell Res 19: 1006-1017, 2009.

27. Moore KJ and Freeman MW: Scavenger receptors in atherosclerosis: beyond lipid uptake. Arterioscler Thromb Vasc Biol 26: 1702-1711, 2006.

28. Goldstein JL and Brown MS: The LDL receptor. Arterioscler Thromb Vasc Biol 29: 431-438, 2009.

29. Mazière $C$ and Mazière JC: Activation of transcription factors and gene expression by oxidized low-density lipoprotein. Free Radic Biol Med 46: 127-137, 2009.

30. Issandou M: Pharmacological regulation of low density lipoprotein receptor expression: current status and future developments. Pharmacol Ther 111: 424-433, 2006.
31. Vainio S and Ikonen E: Macrophage cholesterol transport: a critical player in foam cell formation. Ann Med 35: 146-155, 2003.

32. Sato R: Sterol metabolism and SREBP activation. Arch Biochem Biophys 501: 177-181, 2010.

33. Osborne TF and Espenshade PJ: Evolutionary conservation and adaptation in the mechanism that regulates SREBP action: what a long, strange tRIP it's been. Genes Dev 23: 2578-2591, 2009.

34. Bengoechea-Alonso MT and Ericsson J: SREBP in signal transduction: cholesterol metabolism and beyond. Curr Opin Cell Biol 19: 215-222, 2007.

35. Shimano H: SREBPs: physiology and pathophysiology of the SREBP family. FEBS J 276: 616-621, 2009.

36. Liu J, Zhang F, Li C, Lin M and Briggs MR: Synergistic activation of human LDL receptor expression by SCAP ligand and cytokine oncostatin M. Arterioscler Thromb Vasc Biol 23: 90-96, 2003.

37. Gierens H, Nauck M, Roth M, Schinker R, Schürmann C, Scharnagl H, Neuhaus G, Wieland H and März W: Interleukin-6 stimulates LDL receptor gene expression via activation of sterolresponsive and $\mathrm{Spl}$ binding elements. Arterioscler Thromb Vasc Biol 20: 1777-1783, 2000.

38. Hansson GK: Inflammatory mechanisms in atherosclerosis. J Thromb Haemost 7 (Suppl 1): 328-331, 2009.

39. Ye Q, Chen Y, Lei H, Liu Q, Moorhead JF, Varghese Z and Ruan XZ: Inflammatory stress increases unmodified LDL uptake via LDL receptor: an alternative pathway for macrophage foam-cell formation. Inflamm Res 58: 809-818, 2009.

40. Chen Y, Ruan XZ, Li Q, et al: Inflammatory cytokines disrupt LDL-receptor feedback regulation and cause statin resistance: a comparative study in human hepatic cells and mesangial cell. Am J Physiol Renal Physiol 293: F680-F687, 2007.

41. Ruan XZ, Moorhead JF, Fernando R, Wheeler DC, Powis SH and Varghese Z: Mechanisms of dysregulation of low-density lipoprotein receptor expression in vascular smooth muscle cells by inflammatory cytokines. Arterioscler Thromb Vasc Biol 26: $1150-1155,2006$.

42. Ruan XZ, Varghese Z, Powis SH and Moorhead JF: Dysregulation of LDL receptor under the influence of inflammatory cytokines: a new pathway for foam cell formation. Kidney Int 60: 1716-1725, 2001. 